\title{
Black History in Finland
}

\author{
By Jeremy P. Felt
}

While it is always difficult to convey the real Flavor of the history of one's owll country to foreigners, some aspects of that history bridge the gap more easily than do others. As a recent Fulbright lecturer in American history at Helsinki University I had an unusual opportunity to test this hypothesis. One of my lecture courses was on the history of the black American. My problem was two fold. First, in spite of the influence of Scandinavians such as Gunnar Myrdal, the overwhelming majority of the Finnish students with whom I discussed this subject derived their impression of America's racial crisis from the public media: films, newspapers and magazines, and television. There are, practically speaking, no blacks in Finland, and the very few who do come are likely to be artists or political expatriates (the visit to Helsinki during 1969 of Bobby Seale and of Stokely Carmichael and his wife, singer Miriam Makeba, is a case in point). There is no real conception of what a black community is, or of what the rural South or the Northern ghetto is because there has been no opportunity to live in proximity to large numbers of blacks. My second problem was that as a white I had to attempt to convey the black experience through the filter of my race and to a culture which had no practical experience of blacks.

One may ask at this point how anything productive could have occurred. My feeling is that the semester was profitable, certainly for me and hopefully for my students. As a resident of Vermont, an American state of some 425,008 persons of whom only a few hundred are black, I had some experience in presenting black history to all-white classes. Usually over half of the students would have no experience whatever of blacks; those who did have such experience carnie from outside Vermont. It is of course clear that no one but a black can tell what it is really like to be black and convey the essence of the 
black experience. But the black professor also runs risks. One is that his students may well suffer a lapse of critical judgment, in spite of his best efforts, because of their conscious or unconscious feeling of racial responsibility for the outrageous treatment of blacks throughout their history. It is also true that human beings tend to reduce lectures to ritualistic occasions and that lectures by blacks to whites whose relationship to blacks is more symbolic than real may well become a kind of flagellation experience in which the black details outrages and the white murmurs »Isn't that terrible!»

When one balances the problems laced by both blacks and whites who attempt to lecture on the subject of blacks he may find that the problems are cqual and that a case can be made out for the white as the person best suited to convey black history to other whites. The destinies of the white and colored races of the world are inextricably linked. It is therefore the right of each race to comment on, study and interpret the history of the other until we arrive at that point where what matters is the correction, by whatever means necessary, of the faults in the social system made evident by a study of the country's history, regardless of the racial point from which such a study starts.

Is it possible, then, for a white to present the history of the black man in America to Finnish students? I think that it is not only possible, but that there is much to be said in favor of more study of the American black experience by Finnish students and professional scholars. There are two potentially beneficial ways in which this problem can be approached. One is to study the American black experience as a part of the »third world» phenomenon and as part of the »revolution of rising expectations >>. These matters are of great interest to Finnish university students: witness the recent controversy among university students in Helsinki over the Biafran question. More importantly, such studies would make a direct connection between historical data and the efforts of Finns to create and improve trade relations with areas outside Europe and North America. It would contribute to more understanding of general world economic problems and the aspirations of the "underdeveloped" non-European world and thus relate directly to the economic future of Finland as a small country facing an ever-shifting world economy.

The other approach would be to study the history of the American 
black as one way of assisting Finnish students in the study of social analysis. Already deeply interested in the social problems of their own country and in the re-structuring of their university system, Finns might find in the American black experience some additional analytical devices which could prove useful. I am not competent to suggest how certain of the social problems of Finland might be ma, but I would like very much, for example, to see a comparative study of the experience of the American black in relation to that of gypsies and Lapps in Finland and in Scandinavia. The problem of social alienation, already a concern of some Finnish social commentators, might similarly benefit.

Finally, such studies might very well benefit America most of all. Gunnar Myrdal has cast a long shadow, but his monumental work is being increasingly criticized by blacks on the grounds that he saw black people as essentially white people who happened to be black and not as a functionally autonomous culture. In an earlier issue of this journal Professor Ward Miner spoke eloquently of the value to America of the Scandinavian perspective. Much has changed in America since Myrdal wrote and we need your perspective again. 